NASA Technical Memorandum 83699

\title{
An Overview of the NASA Rotary Engine Research Program
}

Phillip R. Meng, William F. Hady, and Richard F. Barrows

Lewis Research Center

Cleveland, Ohio

Prepared for the 1984 West Coast International Meeting sponsored by the Society of Automotive Engineers

San Diego, California, August 6-9, 1984

\section{N/SA}




\section{AN OVERVIEW OF THE NASA ROTARY ENGINE RESEARCH PROGRAM}

Phillip R. Meng, William F. Hady, and Richard F. Barrows National Aeronautics and Space Administration

Lewis Research Center

Cleveland, Oh10 44135

\section{SUMMARY}

This paper presents a brief overview and technical highlights of the research efforts and studies on rotary engines over the last several years at the NASA Lewis Research Center. The review covers the test results obtained from turbocharged rotary engines and preliminary results from a high performance single-rotor engine. Combustion modeling studies of the rotary engine and the use of a Laser Doppler Velocimeter to confirm the studies are discussed. An in-house program in which a turbocharged rotary engine was installed in a Cessna Skymaster for ground test studies is also covered. Detalls are presented on single-rotor stratified-charge rotary engine research efforts, both in-house and on contract.

\section{INTROOUCTION}

The NASA Lewis Research Center has been working on intermittent combustion (I.C.) propulsion systems for general aviation aircraft since 1973. The initial NASA, FAA, and Contractor efforts were directed toward the measurement and characterization of engine exhaust emissions, in response to the proposed EPA aircraft emissions standards. NASA's program also included consideration of alternative, completely different engine types (such as rotaries) as well as trying to improve the current-production reciprocating engines.

As part of this effort, the Curtiss-Wright RC2-75 aircraft rotary engine (fig. 1) was tested to determine the exhaust emission levels characteristic of this type of engine. The test results showed that the hydrocarbon (HC) emissions exceeded the formerly proposed emissions standard by 39 percent, but both the carbon monoxide (CO) and oxides of nitrogen (NOX) were within the proposed limits. The brake specific fuel consumption (BSFC) at the cruise condition of 77 percent power, was $328 \mathrm{~g} / \mathrm{kW}-\mathrm{hr}(0.54 \mathrm{lb} / \mathrm{bhp}-\mathrm{hr})$. This BSFC was 15 to 20 percent higher than typical, then-current aircraft gasoline piston engines of comparable power. However, the rotary's specific weight was $0.766 \mathrm{~kg} / \mathrm{kW}(1.26 \mathrm{lb} / \mathrm{hp})$, which was about 20 percent lower than typical, nonturbocharged aircraft piston engines.

A follow-on contract with Curtiss-Wright incorporating a higher compression ratio, and other minor modifications to this engine, reduced the cruise BSFC to $274 \mathrm{~g} / \mathrm{kW}-\mathrm{hr}(0.45 \mathrm{lb} / \mathrm{bhp}-\mathrm{hr})$, while meeting the former aircraft exhaust emission standards.

Encouraged by these favorable results. NASA has established a paralle1, in-house rotary engine test program at the Lewis Research Center. Early accomplishments include the development of specialized diagnostic instrumentation 
for rotary combustion processes (ref. 1) 1 and initial tests of a turbocharged rotary engine (ref. 2). In the latter tests, the measured minimum BSFC of an automotive-type rotary engine was improved from $322 \mathrm{~g} / \mathrm{kW}-\mathrm{hr}(0.53 \mathrm{lb} / \mathrm{bhp}-\mathrm{hr})$ to $274 \mathrm{~g} / \mathrm{kW}-\mathrm{hr}(0.45 \mathrm{lb} / \mathrm{bhp}-\mathrm{hr})$ after minor modifications to accept turbocharging and a leaner fuel schedule. The NASA and Curtiss-Wright results tend to confirm that the rotary can be competitive in fuel economy with comparable reciprocating gasoline engines.

Meanwhile, advances in stratifled-charge rotary engine technology were made by Curtiss-Wright in the design and development of the large 5735 $\mathrm{cm}^{3} /$ rotor (350 in $3 /$ rotor) multi-fuel engine (fig. 2) for the United States Navy/Marine Corps. This engine's multi-fuel combustion system and several other features provided the basis for an Advanced Stratifled-Charge Rotary Aircraft Engine Design Study, which was performed under a NASA contract with Curtiss-Wright (ref. 3). Under a more recent NASA contract, Curtiss-Wright initiated the design and fabrication of a single-rotor test engine to evaluate the various technologies needed for an advanced rotary aircraft engine.

\section{WHY A ROTARY AIRCRAFT ENGINE}

In recent NASA and industry studies, the rotary engine was selected as the candidate engine for a general aviation aircraft powerplant. These studies included several small advanced turboprops, an advanced alr-cooled sparkignition engine (ref. 4), a compact two-stroke cycle radial-piston Diesel engine (ref. 5), and a lightweight liquid-cooled, stratified-charge rotary engine (ref. 3). Using these results and related data, airplane/mission evaluation studies of each engine in representative airplane/mission scenarios were conducted both in-house by NASA (ref. 6) and under contract (refs. 7 and 8). The rotary engine performance appeared to be slightly better than that of the Diesel and considerably better than the other candidates. Installation-related advantages and predicted passenger-comfort levels (based on low vibration) were viewed as significant positive factors in the overall rotary evaluation, which only the small turboprop could match. Additional factors that favored the rotary engine were the ease with which the rotary could be adapted to stratified-charge operation (ref. 9) -- thus enabling it to burn jet fuel -and its abllity to be scaled over a wide range of horsepower ratings (ref. 10).

A projected installation drawing for an advanced rotary aircraft engine design is shown in figure 3 . The installation and related advantages are 11lustrated in figures 4 and 5 for a single engine aircraft, and in figures 6 and 7 for a twin. These designs were part of the study by Curtiss-Wright and Cessna (ref. 3) showing the advantages of the advanced design stratified-charge rotary engine. In the final analysis, the Diesel and the rotary were favored from a technical viewpoint, because of their high efficiency; while the turboprop and rotary were favored from a marketing viewpoint, because of the perceived marketing advantage of the installation and lower nolse/vibration signature. Thus, the rotary emerged from the study process as the best candidate - not an overwhelming winner in any one category, but creditably strong in all.

In summary, the stratiffed-charge rotary engine presents a uniquely desirable combination of characteristics: it is reasonably efficient, capable of multi-fuel operation, easily scaleable, and provides attractive installation 
features. In addition to its very strong showing for general aviation applications, more recent studies indicate that it is at least competitive with advanced turboprops for higher-power installations such as commuters (ref. 11) and helicopters (ref. 12). For these reasons, it currently has been selected as the best choice for emphasis in the ongoing intermittent combustion engines research activities.

\section{LEWIS CONTRACT EFFORTS}

A recent contract, "Stratified-Charge Rotary Aircraft Engine Technology Enablement Program," was signed with Curtiss-Wright Corporation in December 1982. On February 1, 1984, Deere and Company acquired the exclusive North American rights to the rotary engine, including all patents, know-how, and experimental engines and components formerly owned by Curtiss-Wright. Currently, Deere and Company is assuming responsibllity for the uncompleted portion of this contract.

The objective and scope of this contract effort is to provide for the design, fabrication, assembly and acceptance testing of a single-rotor research test engine ( $f i g .8$ ) complete with appropriate documentation and spare parts. This test engine will permit the mapping of key performance variables over a broad range of operations. It will also permit the investigation of advanced technologies and definition of the best design parameters for future, advanced aircraft engines of this type.

The overall program consists of four discrete tasks:

Task I: Design of SCRC 1-40T Technology Enablement Test Engine

Task II: Fabrication of the SCRC 1-40T Technology Enablement Test Engine

Task III: Test Engine Assembly and Acceptance Test

Task IV: Reporting

Figure 9 shows the program schedule indicating the current status, the milestones achieved, and milestones to be completed. Figure 10 briefly ind $i_{-}$ cates some of the technologies that need to be pursued in follow-on work. (The schedule to achieve these technologies is subject to possible funding variations over the next several years.) In addition to those listed in figure 10 , further advanced technologies which should be investigated include: adlabatic components, lightweight rotors, high speed apex seal concepts, and material compatability studies for seals and housings. Given appropriate and continuing NASA and industry commitments, the results of these efforts will be factored into the design of an advanced stratified-charge rotary engine, for commercial development and certification by the early 1990's.

\section{LEWIS IN-HOUSE RESEARCH PROGRAMS}

\section{Outboard Marine Corporation (OMC) Engine}

A single-rotor, $655 \mathrm{~cm}^{3}\left(40 \mathrm{in}^{3}\right)$ displacement direct-injected, stratifiedcharge engine was obtained from the OMC in October 1983. This experimental 
engine (fig. 11) will be used to accomplish the following objectives:

demonstrate performance using Jet-A fuel with the OMC charge-cooled rotor design and Curtiss-Wright/Deere pllot injection configuration; (2) obtain performance and combustion data for two different combustion chamber geometries; (3) validate the improved method of obtaining pressure and combustion data from multiple pressure transducers; and (4) evaluate the effectiveness of improved performance by using micro computer control systems on the fue 1 injection and ignition system. The initial testing will be conducted on the "as received" engine. All testing will be conducted with complete engine instrumentation to obtain, engine performance data, detalled energy balance, and combustion data. The engine will then be modified with a combustion system similar to the Curtiss-Wright/ Deere system used in SCRC 1-40T baseline testing. A complete series of engine tests will be conducted on the modified engine.

\section{Turbocharged Rotary Engine Tests}

Limited exploratory investigations of the sea-level power and economy characteristics of a turbocharged rotary engine were conducted during 1982/ 1983. The basic test engine was a model 12A (nonemissions type) Mazda tworotor gasoline engine of $573 \mathrm{~cm}^{3}\left(35 \mathrm{in}^{3}\right)$ displacement per rotor. The engine was fully. instrumented and installed in an electric-dynamometer test cell, using a manual transmission to match the engine and dynamometer speeds. Detalls on the facility, instrumentation and test conditions have been reported in (ref. 2).

After baseline testing of the unmodified engine, two turbocharged versions were assembled with commerclally-available turbochargers of the general type shown in figure 12. Both turbocharger installations were similar to that shown in figure 13. Carburetion and boost pressure levels for each installation were specified for the turbocharger under test.

The performance resulting from each turbocharged bulld is compared with the naturally-aspirated (N.A.) baseline data in figure 14. The latter shows a maximum power of $89 \mathrm{~kW}(119 \mathrm{bhp})$ at $7000 \mathrm{rpm}$. The first turbocharged bulld used the stock (small-venturi) carburetor and a conservative boost pressure limit of $48.3 \mathrm{kPa}(7 \mathrm{psig})$ to obtain $114 \mathrm{~kW}$ (153 bhp) at $6000 \mathrm{rpm}$. This represents a 36 percent power boost with minimal stress on the engine structure. The second bulld used a high-flow aftermarket carburetor and increased boost of $69.7 \mathrm{kPa}(10.1 \mathrm{ps} / \mathrm{g})$ to develop $143 \mathrm{~kW}(191 \mathrm{bhp})$ at $7000 \mathrm{rpm}--$ a 61 percent power increase.

Steady state cruise test data were also collected at $78 \mathrm{~kW}$ (105 bhp) with both lean and rich carburetor jets with the first turbocharged build as shown in figure 15. The most economical test point obtained was $274 \mathrm{~g} / \mathrm{kW}-\mathrm{hr}$ ( $0.45 \mathrm{lb} / \mathrm{bhp}-\mathrm{hr}$ ) on the lean (lower) curve at $4000 \mathrm{rpm}$ and $78 \mathrm{~kW}$ (105 bhp). However, at the lean operating conditions, the turbine inlet temperature exceeded the maximum allowable temperature of $900^{\circ} \mathrm{C}\left(1650^{\circ} \mathrm{F}\right)$ by approximately $110^{\circ} \mathrm{C}\left(200^{\circ} \mathrm{F}\right)$. Continued operation at these conditions over an extended perlod of time would cause fallure of the turbine. 


\section{High Performance Single Rotor Engine Program}

Two custom built, $573 \mathrm{~cm}^{3}\left(35 \mathrm{in}^{3}\right)$ displacement, single-rotor engines were obtained to support in-house rotary engine aircraft research programs. Several of these programs will be discussed in more detail later on in this paper. One additional program that will make use of this high performance single-rotor engine is an apex seal program designed to evaluate new seal materials and seal concepts.

The engines were built from 1980 12A Mazda engine parts, modified to accommodate an existing single-rotor shaft. Housing sets were modified to allow either a bridge-ported or a peripheral-ported engine configuration. Figure 16 is a photograph of the bridge-ported engine before installation. Each engine was designed to produce 82 to $97 \mathrm{~kW}(110$ to $130 \mathrm{hp}$ ) at a rotative speed in the range of 9000 to $9500 \mathrm{rpm}$, naturally aspirated. The engines were provided with crank triggered CDI type ignition systems and Weber model 44-1DF-38-IC carburetors adapted to each particular engine configuration. The use of stock parts in building up these engines simplified the installation in an existing, fully instrumented rotary engine test facility as shown in figure 17 .

The bridge-ported engine has been installed and has been operated at speeds to $9000 \mathrm{rpm}$ for short durations. More recent running of the engine, up to $8000 \mathrm{rpm}$ has been accomplished for longer periods to establish an optimum running speed and throttle setting for long duration seal testing. Some preliminary results of this testing are presented in figure 18. The data indicate that the engine can be run for long perlods of time at $7000 \mathrm{rpm}$ at a throttle setting of 75 percent, without excessive overheating of the coolant and lubrication systems. The nominal BSFC at this setting was $316 \mathrm{~g} / \mathrm{kW}-\mathrm{hr}$ $(0.52 \mathrm{lb} / \mathrm{bhp}-\mathrm{hr})$ at an air/fuel ratio of $14: 1$ with a measured output of $61 \mathrm{~kW}$ ( 82 bhp).

\section{Material Research for Advanced Rotary Engines}

Most of the high temperature material research for the last ten years has been directed at improving the gas turbine engine, and to a lesser extent the Diesel engine. In order to take advantage of these new materials for use in the rotary engine, Lewis Research Center has established a program that includes both experimental testing and analytical analysis of all major engine components.

One current in-house program is directed at analytically establishing the thermal boundary conditions using an existing rotary engine combustion computer code developed by the Massachusetts Institute of Technology. Cambridge, Massachusetts. The validity of this computer code will be verified with test data obtained from an instrumented, single-rotor engine. Figure 19 is a photograph of the trochoid housing that will be used in these tests. The housing has been fitted with thermocouples to evaluate heat transfer, and with trielement strain gages to determine the stresses caused by the engine loads. The majority of the instrumentation is located at the critical region around the spark plugs.

Further use of the information obtained through in-house testing will support the development of several finite-element computer design codes. One 
code to evaluate rotor housing deformation and its subsequent effect on apex seal performance, is being developed through a grant to Michigan Technological University, Houghton, Michigan. Contract work at Analys is and Design

Application Company, Ltd. (ADAPCO) will further utilize the results in their finite-element analysis in a feasibility design study of engine components plasma sprayed with thermal barrier coatings. Two thermal barrier coated rotors are shown in figure 20. Because of the unique combustion chamber shape of the rotary engine, the relative benefits of thermal barrier coatings may be greater than with other engines. The rotary engine has a larger coolant heat rejection, and combustion tends to be slow in its elongated, highly-quenched combustion region. Reduction of these cooling losses should result in faster combustion (by replacing cool quench areas with hot reaction-promoting areas) and increase the energy avallable in the exhaust gases which can be partially recovered with turbocharging or turbocompounding (ref. 14).

In addition to the thermal barrier coating work, testing will be carried out on new ceramic apex seal material combinations. Material compatibility testing will be done either in-house or on contract, depending upon which is most cost effective and which is the most timely. Figure 21 shows a standard rotor with partially stabilized zirconia (PSZ) apex seals, one of the proposed materials.

\section{Ground Test Alrcraft Program}

A ground test facllity bullt from a military surplus 0-2A Cessna Skymaster aircraft as shown in figure 22 , is being used to study engine/airframe integration and cooling problems with liquid-cooled rotary engines. The same facility provides a test-bed for conducting research on the performance and wear of rotary. engine components in a representative test. environment with aircraft and propelier induced dynamics and vibration.

The Skymaster aircraft has twin air-cooled engines in a push-pull configuration. Tri-axial vibration pickups were installed on the forward reciprocating engine, the firewa 11, instrument pane1, and co-pilots seat rall for the initial testing. Baseline vibration and cabin noise tests were conducted by operating the forward engine over a range of test conditions. The continental $0-360,157 \mathrm{~kW}(210 \mathrm{hp})$, reciprocating engine was removed as shown in figure 23 , and the engine mounting was modified to accept the rotary engine.

A Mazda 13B, $655 \mathrm{~cm}^{3} /$ rotor (40 in $3 /$ rotor) two-rotor engine was modifled as shown in figure 24 by installing a cog belt propeller reduction system. The belt reduction ratio will be determined by dynamometer testing of the engine, but it is expected to be approximately a $3: 1$ reduction. The engine will be turbocharged so that a takeoff power of $157 \mathrm{~kW}(210 \mathrm{hp})$ may be achieved.

A complete data collector system, similar to the system shown in figure 25, has been installed on mounting racks in the aft section of the 0-2A cabin. The initial test program is shown in figure 26.

This facility will be used for testing several rotary engines of different horsepower ratings and will eventually be used for testing a stratified-charge rotary aircraft engine from the ongoing research programs. 


\section{Rotary Engine Combustion Process Research}

In the area of combustion research, programs have been established for both the rotary and piston engines to gain a fundamental understanding of the internal processes that occur within the engine. These efforts include both numerical simulation and detalled experimental studies. These are covered in detail in reference 13.

Numerical simulation studies of the fluid flow, heat transfer, and combustion processes inside the combustion chamber of a direct-injection, stratifiedcharge rotary engine are in progress through a grant at the University of Florida, Gainesville, Florida. These two-dimensional and three-dimensional codes, based on the Navier-Stokes equations, are being developed to study an idealized two-dimensional rotary engine as well as a more realistic threedimensional rotary engine. An example of the preliminary output of the twodimensional code is shown in figure 27 . At the present time, various boundary conditions for the intake, exhaust, and fuel-injection ports are still being tested for accuracy and numerical stability. The development of the threedimensional code is still in the programming stage.

A schematic of the rotary engine combustion chamber flow visualization system is shown in figure 28 . The system consists of the modified singlerotor engine configuration, the pulsed ruby laser, the holocamera, and an ac drive motor. The front and rear end housings have been modified to permit the installation of four sapphire windows, (two per housing) for access to the combustion chamber. Additional modifications include end housing coolant pas.sages, main journal bearings, and consideration of replacing the metallic apex and side seals with seals that would be more compliant. The engine with the sapphire windows is currently in the assembly stage and planned for completion by late summer, with an initial check-out of the rotating components to follow. A check-out of the total system while motoring at $3000 \mathrm{rpm}$ will be accomplished under a contract with installation at the Lewis Research Center by the end of the year.

\section{SUMMARY}

Studies at NASA and several aircraft and engine companies indicate that the rotary engine is a viable candidate for future light aircraft propulsion systems. These studies have shown that fuel savings on the order of 25 to 50 percent are possible and could result in a substantial reduction in the world aviation gasoline fuel consumption. The status of the research and technology programs at NASA Lewis Research Center for the advancement of the rotary engine for light aircraft is listed below.

The original NASA/Curtiss-Wright contract for the design, fabrication. and acceptance testing of an advanced stratified-charge rotary test engine has been taken over by Deere and Company, and is nearing completion.

In-house testing of a small stratifled-charge engine from the Outboard Marine Corporation is in progress.

Turbocharged rotary engine testing has been completed and results showed 36 to 61 percent increases in power with commercially avallable turbo systems. 
Combined with a lean fuel schedule, this also resulted in a significant increase (approximately 180 percent) in cruise fuel economy.

High temperature material research for rotary engines has begun with both analytical studies (computer codes) and experimental verification of engine components to determine their potential for advanced rotary applications. Ceramic coated rotors and ceramic apex seals are scheduled to be tested in the high performance single-rotor engine.

Preparation for ground testing of rotary engines in an aircraft installa$t$ ion have been initiated. Several rotary engines of varying horsepowers, engine to propeller gear ratios, and propellers are planned for future testing. A stratifled-charge engine will also be tested in this factilty when avallable.

Combustion modeling on rotary engines with numerical simulation of flow in the combustion chamber is in progress. Experimental verification utilizing a flow visualization engine and a Laser Doppler Velocimeter is expected to start by the end of 1984 .

\section{REFERENCES}

1. Schock, H. J., Rice, W. J., and Meng, P. R., "Experimental Analysis of IMEP in a Rotary Combustion Engine," SAE Paper 810510, February 1981.

2. Meng, P. R., Rice, W. J., Schock, H. J., and Pringle, D. P., "Preliminary Resuits on Performance Testing of a Turbocharged Rotary Combustion Engine," SAE Paper 820354, February 1982.

3. Badgley, P., Berkowitz, M., Jones, C., Myers, D., Norwood, E., Pratt, W. B. Mueller, A., Ellis, D. R., Huggins, G., and Hembrey, J. H., "Advanced Stratified-Charge Rotary Engine Design Study," Curtiss-Wright, Wood-Ridge, NJ, CW-WR-81.021, January 1982, NASA CR-165398.

4. Stuckas, K. J., "Advanced Technology Spark-Ignition Aircraft Piston Engine Design Study," Teledyne Continental Motors, Mobile, AL, NASA CR-165162, November 1980.

5. Browers, A. P., "A 150 and $300 \mathrm{~kW} \mathrm{Lightweight} \mathrm{Diesel} \mathrm{Aircraft} \mathrm{Engine}$ Design Study," NASA CR-3260, Apri1 1980. Also Browers, A. P.. "Design Study: A $186 \mathrm{~kW}$ Lightweight Diesel Aircraft Engine," NASA CR-3261, Apr 11 1980.

6. Wickenheiser, T. J., Knip, G., Plencer, R. M., and Strack, W. C., "Comparisons of Four Alternative Powerplant Types for Future General Aviation Aircraft," NASA TM-81584, October 1980.

7. Zmroczek, L. A., "Advanced General Aviation Comparative Engine/Airframe Integration Study," Beech Atrcraft Corporation, Boulder, CO, NASA CR-165565, Apri1 1982 .

8. Huggins, G. L., and Ellis, D. R., "Advanced General Aviation Comparative Engine/Airframe Integration Study," Cessna Aircraft Company, Wichita, KS, Cessna AD-217, NASA CR-165564, Apri1 1982. 
9. Jones, C., "An Update of Applicable Automotive Engine Rotary StratifiedCharge Developments," SAE Paper No. 820347, February 1982.

10. Berkowitz, M., Jones, C., and Myers, D., "Study of Advanced Rotary Combustion Engines for Commuter Aircraft," Curtiss-Wright Corporation, Wood-Ridge, NJ, CW-WR-81.022f, NASA CR-165399, February 1982.

11. Willis, E. A., "Development Potential of Intermittent Combustion (I.C.) Aircraft Engines for Commuter Transport Applications," NASA TM-82869, 1982.

12. Wilsted, H. D., "Preliminary Survey of Possible Use of Adiabatic Diesel for Helicopter," SAE Paper No. 820432, February 1982.

13. Schock, H. J., "A Review of I.C. Engine Combustion Chamber Process Studies at NASA Lewts Research Center," AIAA Paper No. 84-1316, June 1984.

14. Willis, E. A., and Wintucky, W. T., "An Overview of NASA I.C. Engine Research," AIAA Paper No. 84-1393, June 1984. 


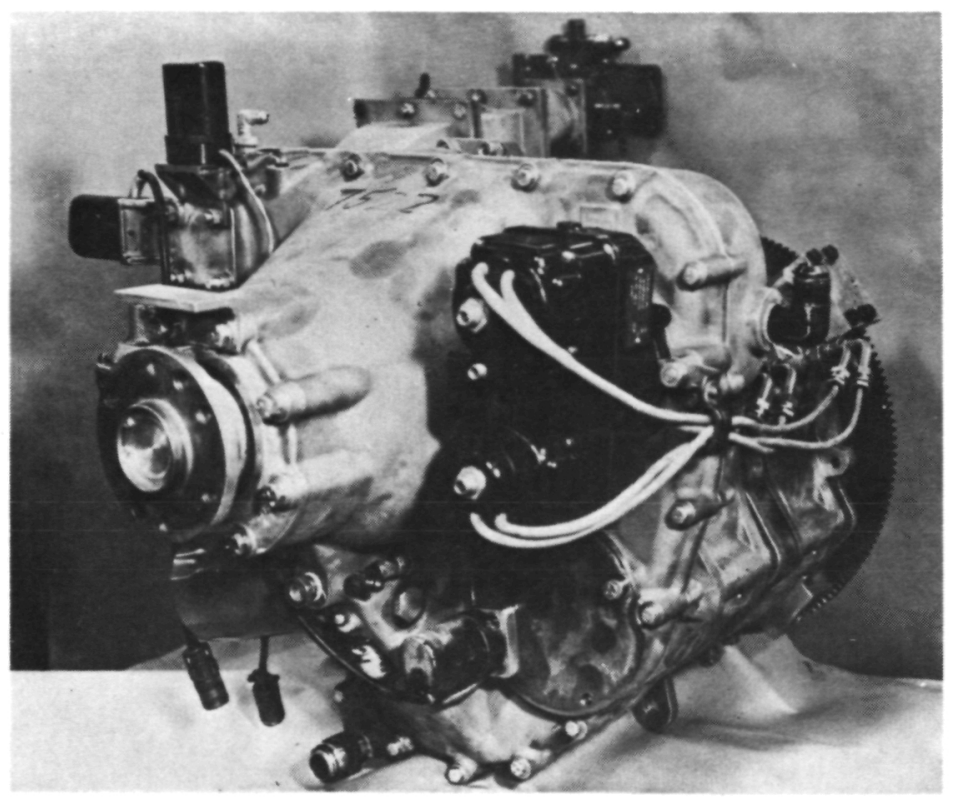

Figure 1. - The RC2-75 rotary engine.

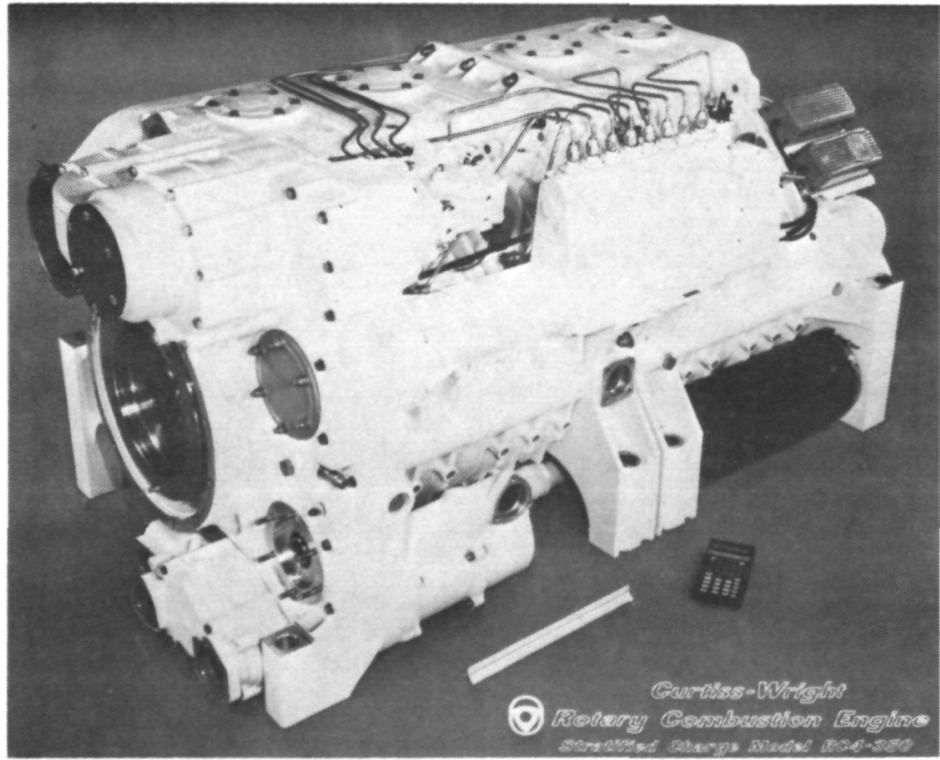

Figure 2. - Curtiss-Wright rotary combustion engine stratified charge model RC4-350. 


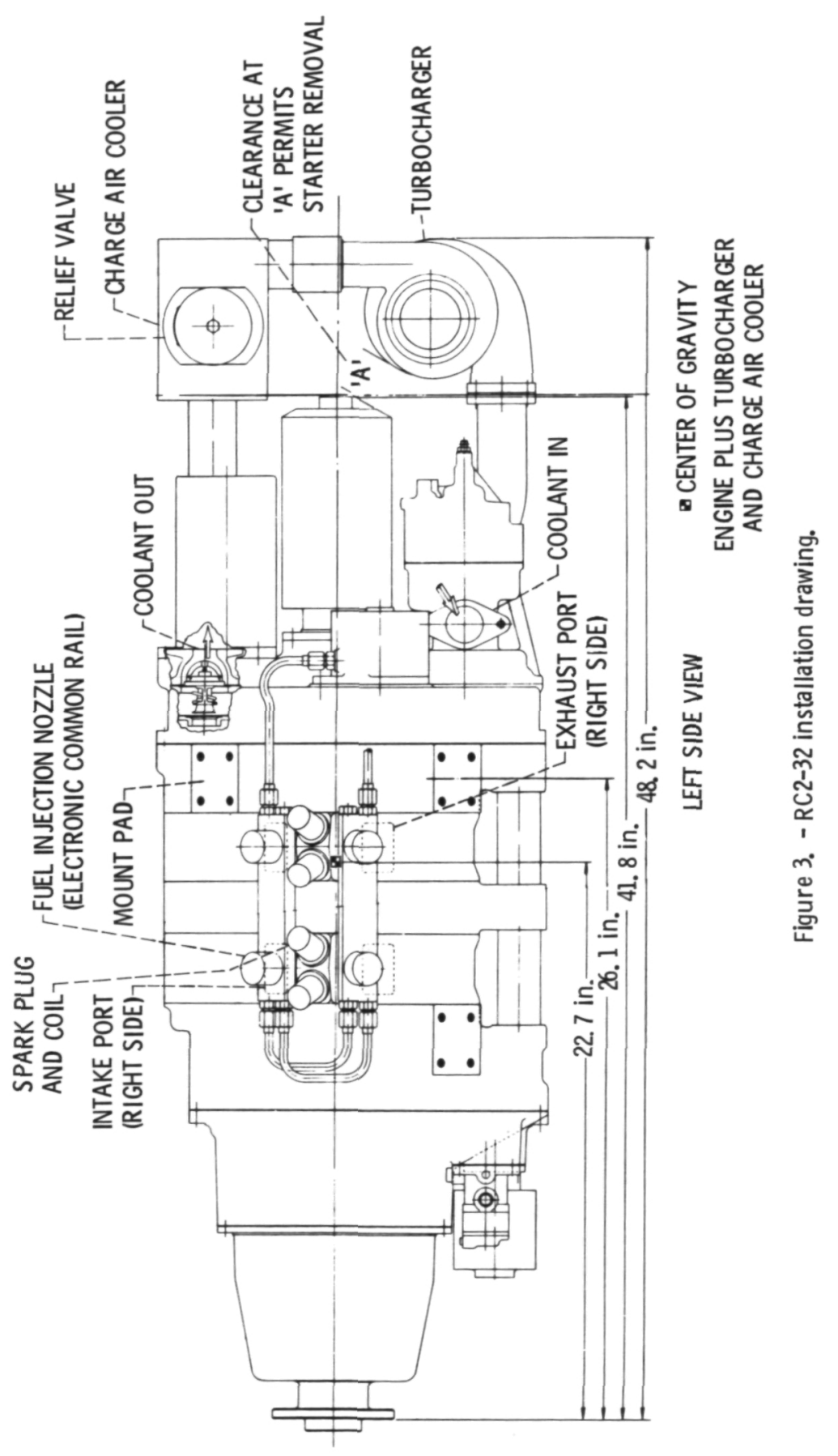




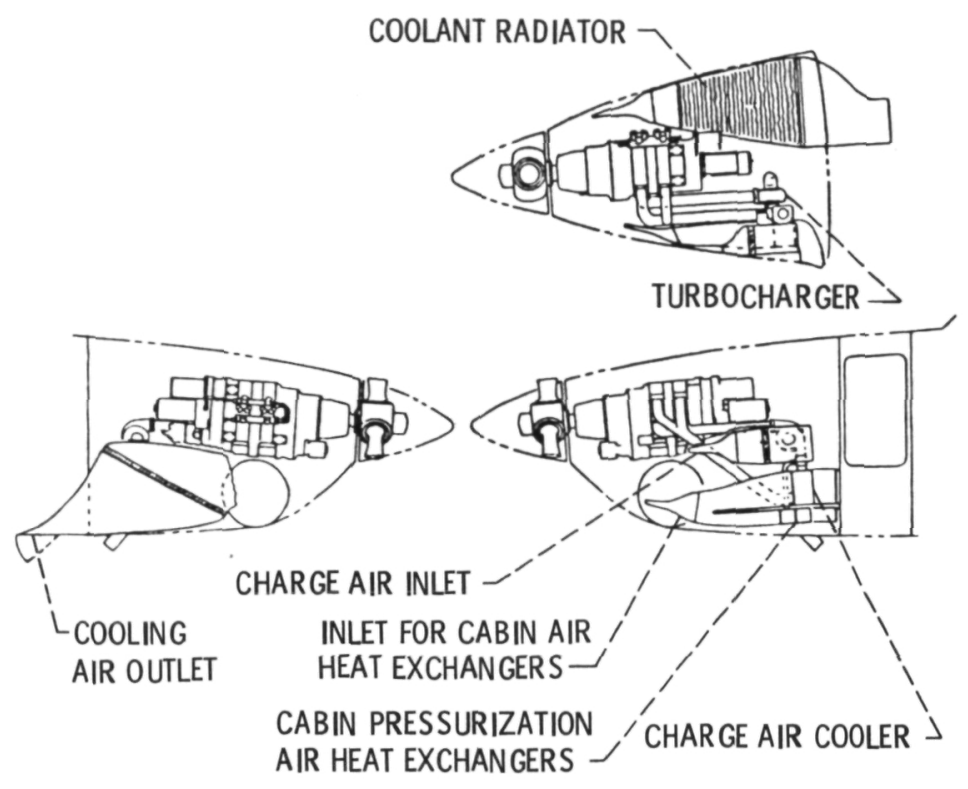

Figure 4. - RC2-32 highly advanced rotary engine - single-engine installation concept.
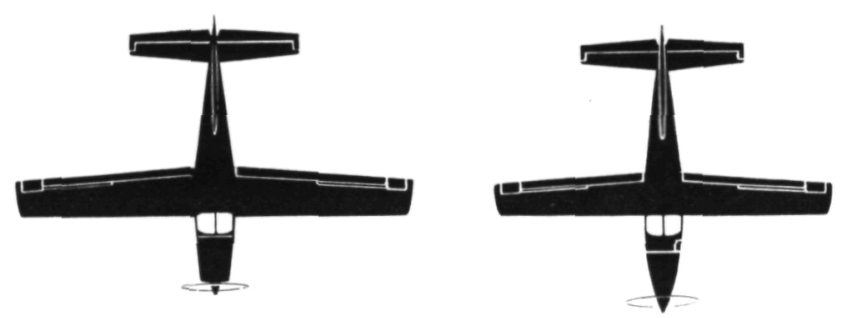

$\underline{\text { TSI0-550 }}$

ENGINE

$\underline{\mathrm{RC} 2-32}$
12. $2 \mathrm{~m}(39.9 \mathrm{ft})$
SPAN
$10.8 \mathrm{~m}(35.4 \mathrm{ft})$
$16.4 \mathrm{~m}^{2}\left(177 \mathrm{ft}^{2}\right)$
AREA
$13.2 \mathrm{~m}^{2}\left(142.5 \mathrm{ft}^{2}\right)$
9. 0
ASPECT RATIO
$8.8 \quad 8.8$
$1035 \mathrm{~kg}(2282 \mathrm{lb})$
BASIC EMPTY WEIGHT
$1007 \mathrm{~kg}(2220 \mathrm{lb})$
$2064 \mathrm{~kg}(4550 \mathrm{lb})$
GROSS WEIGHT
$1712 \mathrm{~kg}(3775 \mathrm{lb})$
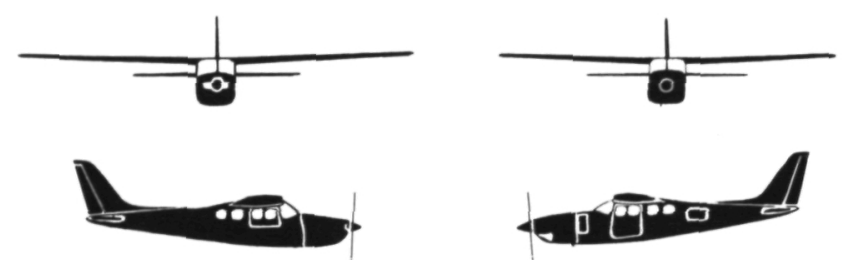

Figure 5. - Baseline and RC2-32 singles. 


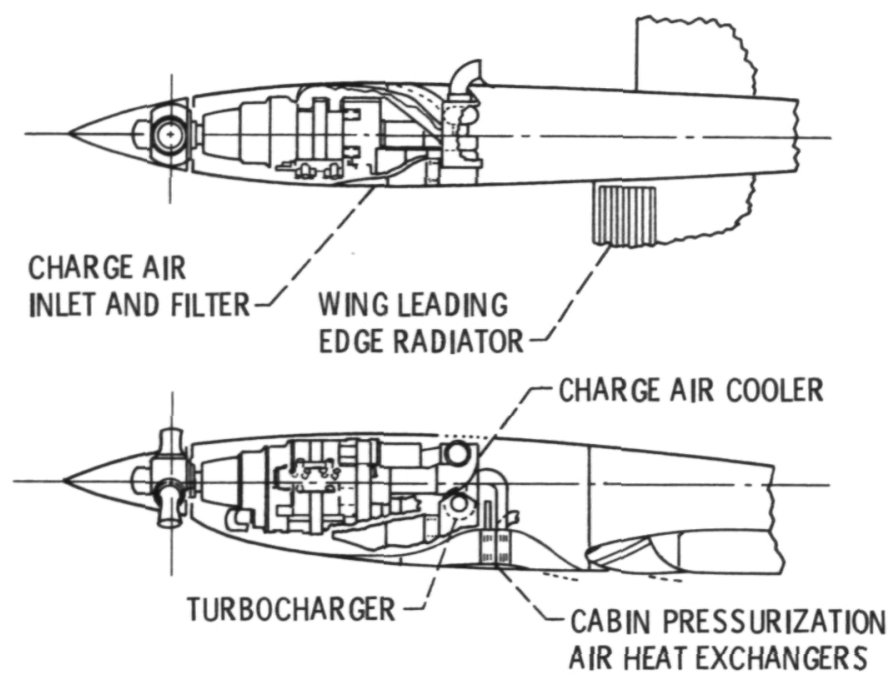

Figure 6. - RC2-32 highly advanced rotary engine - twin-engine installation concept.

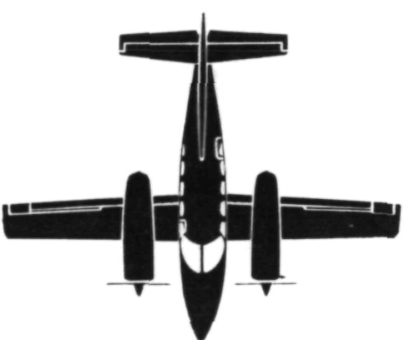

TSI0-550

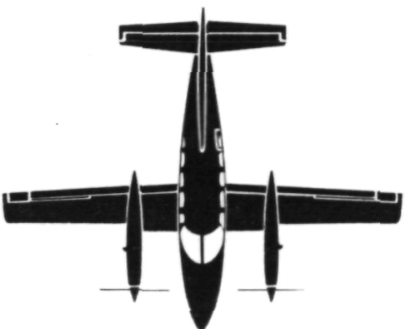

ENGINES

RC2-32

$12.2 \mathrm{~m}(40.0 \mathrm{ft})$

$15.8 \mathrm{~m}^{2}\left(170.0 \mathrm{ft}^{2}\right)$

9.5

9. 5

SPAN

AREA

ASPECT RATIO

$2.6 \mathrm{~m}(41.3 \mathrm{ft})$

$1906 \mathrm{~kg}(4203 \mathrm{lb})$

BASIC EMPTY WEIGHT

$14.4 \mathrm{~m}^{2}\left(155.0 \mathrm{ft}^{2}\right)$

$3005 \mathrm{~kg}(6625 \mathrm{lb})$

GROSS WEIGHT

$11.0 \quad 11.0$

$1483 \mathrm{~kg}$ (3269 lb)

$2438 \mathrm{~kg}$ (5375 lb)
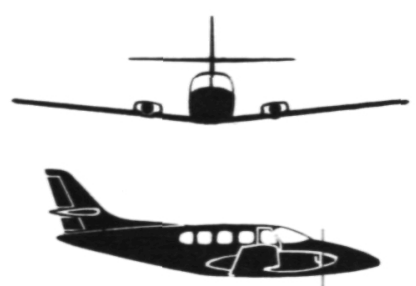
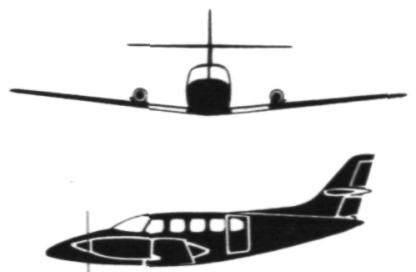

Figure 7. - Baseline and RC2-32 twins. 


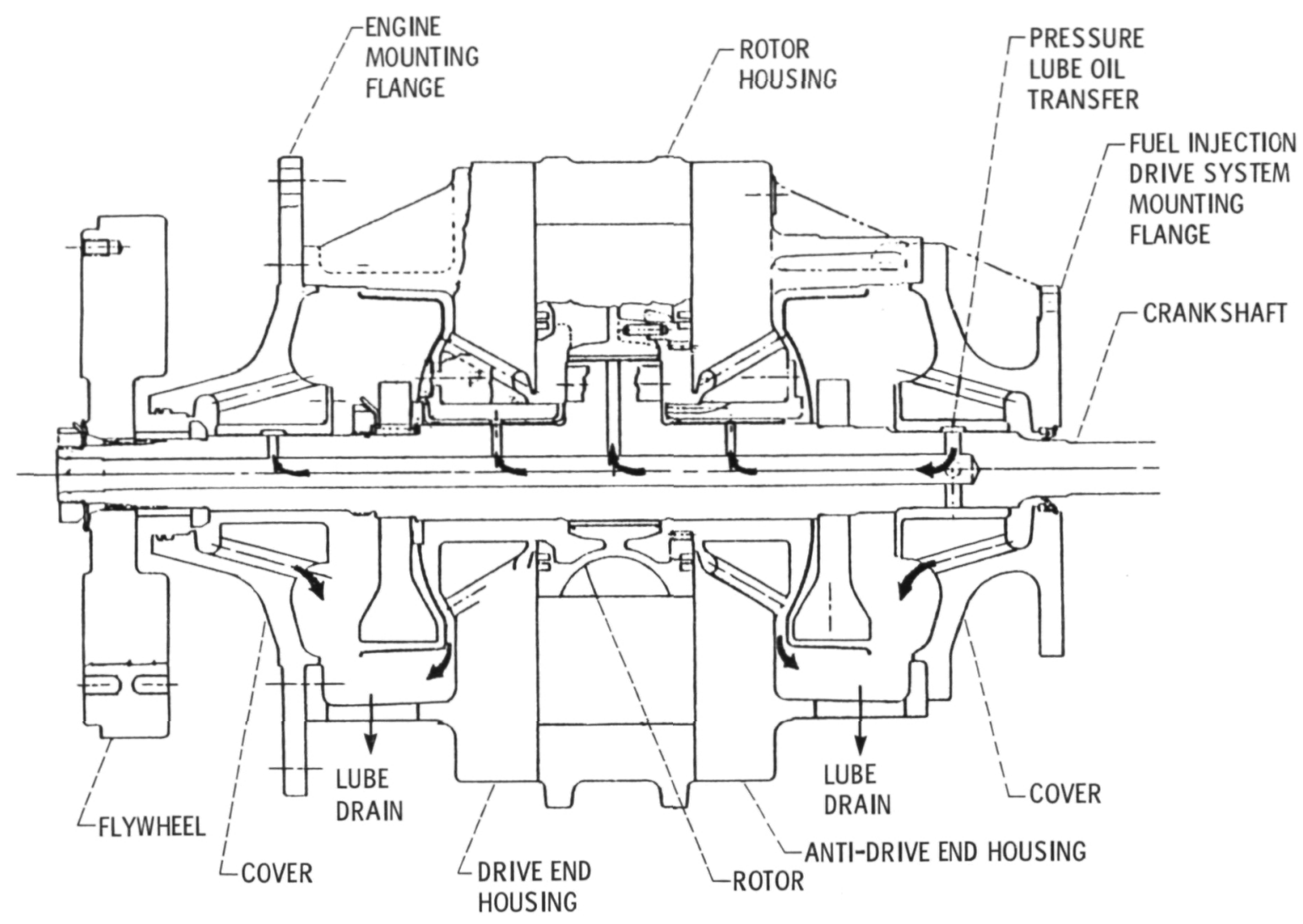

Figure 8. SCRCl - 40T engine cross-section.

STRATIFIED-CHARGE ROTARY ENGINE (NAS3-23056)

SCRCl-40T

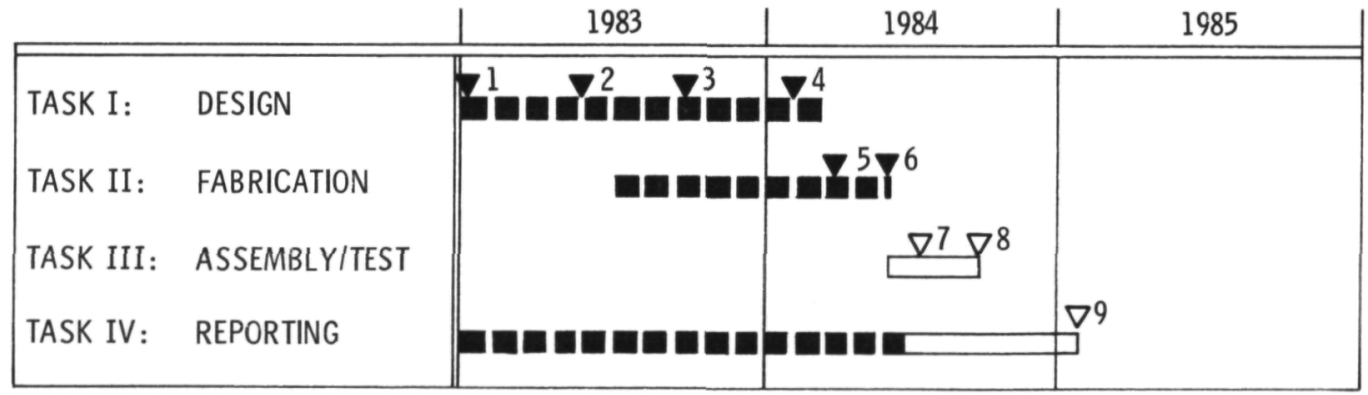

MAJOR MILESTONES :

1. START OF CONTRACT JANUARY 1, 1983

2. PRELIMINARY DESIGN REVIEW MAY 18, 1983

3. FINAL DESIGN REVIEW SEPTEMBER 29, 1983

4. JOHN DEERE ACQUIRED R. E. ASSETS

FEBRUARY 1, 1984
5. ALL PROCUREMENTS

6. FACILITY READY

7. ASSEMBLY

8. TEST

9. FINAL REPORT

Figure 9. - Technology enablement program schedule.

$\nabla$ COMPLETED

$\nabla$ TO BE COMPLETED 
- BASIC PERFORMANCE EVALUATIONS

-BASELINE TESTING

- INJECTION SYSTEM

- SPARKPLUG CHARACTERIZATION

- INITIAL PARAMETRIC EVALUATION

COMPRESSION RATIO

HIGH BMEP RUNS

HIGH SPEED EVALUATION

- INSTRUMENTED ENGINE

- THERMAL SURVEYS/ROTOR AND ROTOR HOUSING

- HEAT REJECTION EVALUATIONS

- ADVANCED FUEL-INJECTION SYSTEM

- TURBOCHARGER DEVELOPMENT

- IMPROVED COMBUSTION

- PLASMA JET IGNITION

- ADVANCED FUEL INJECTION SYSTEM

- HOT SPOT/GROW PLUG IGNITION

Figure 10. - Proposed technology program.

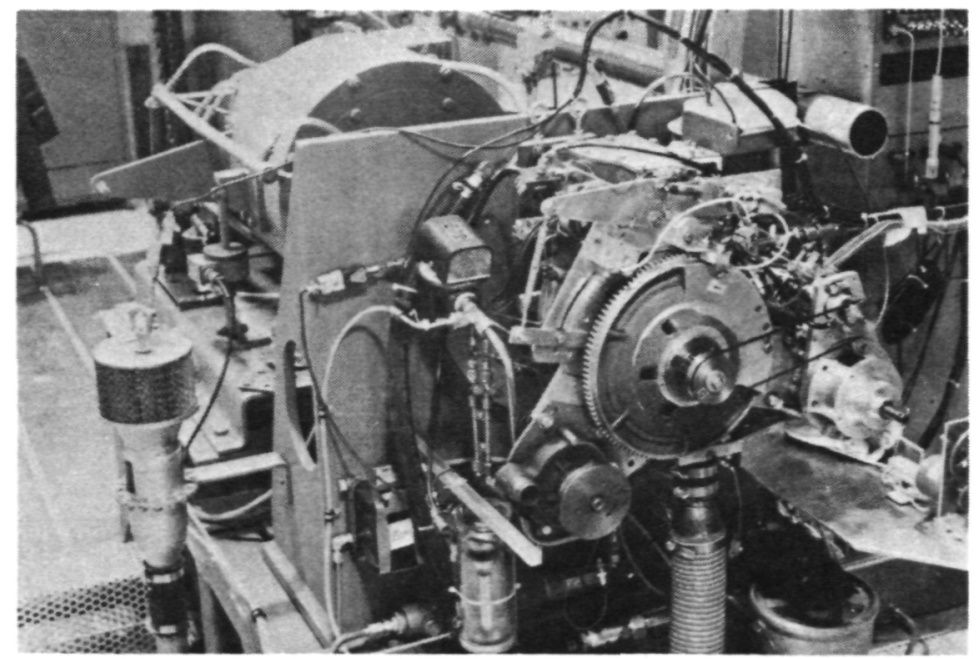

Figure 11. - OMC single rotor engine installation. 


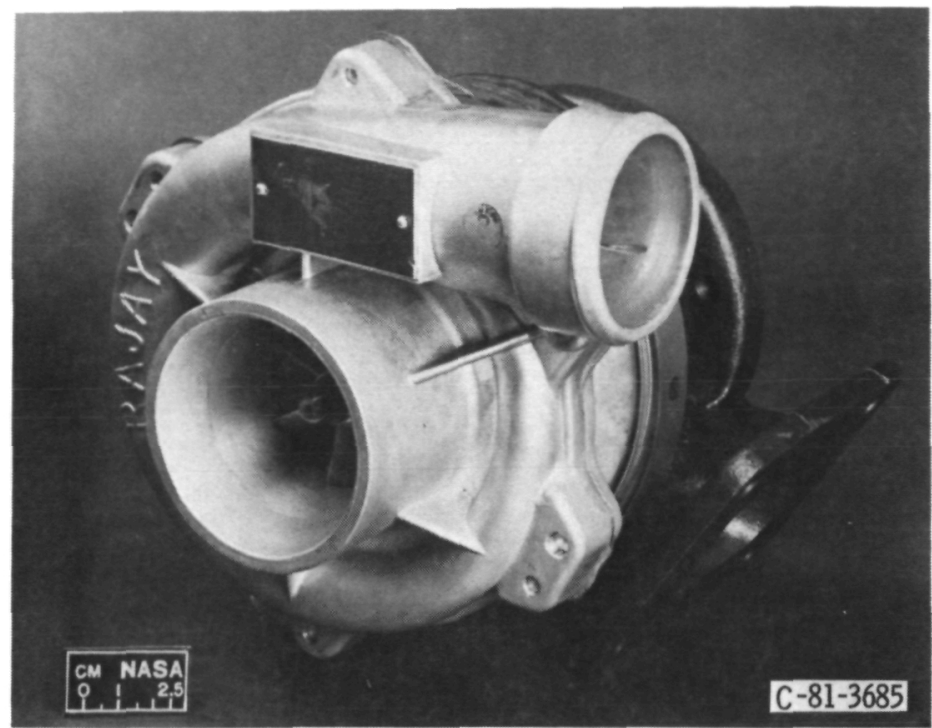

Figure 12. - Commercially available turbocharger.

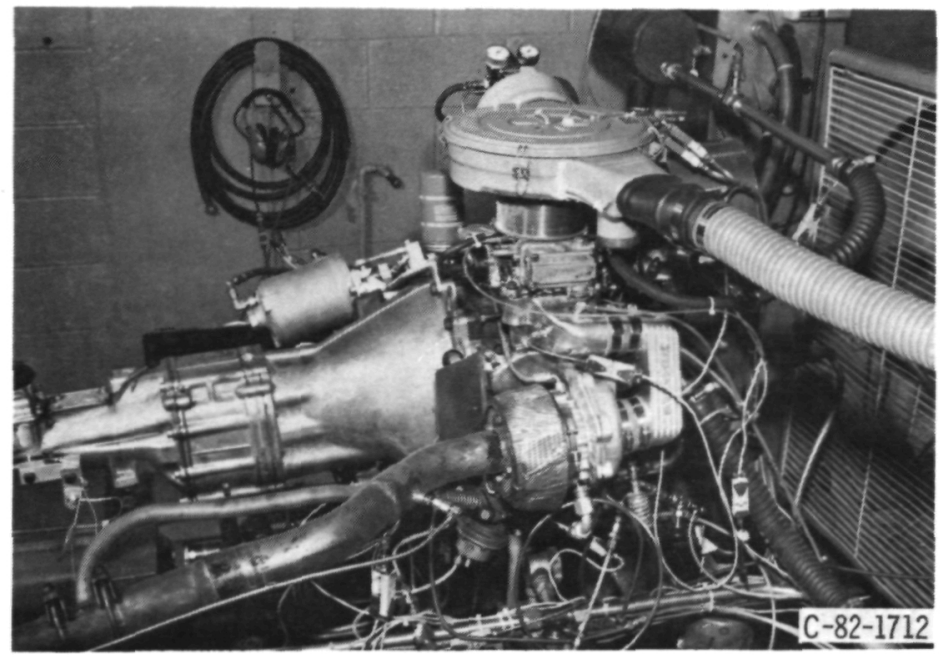

Figure 13. - Rotary engine with Arkay turbocharger system installed. 


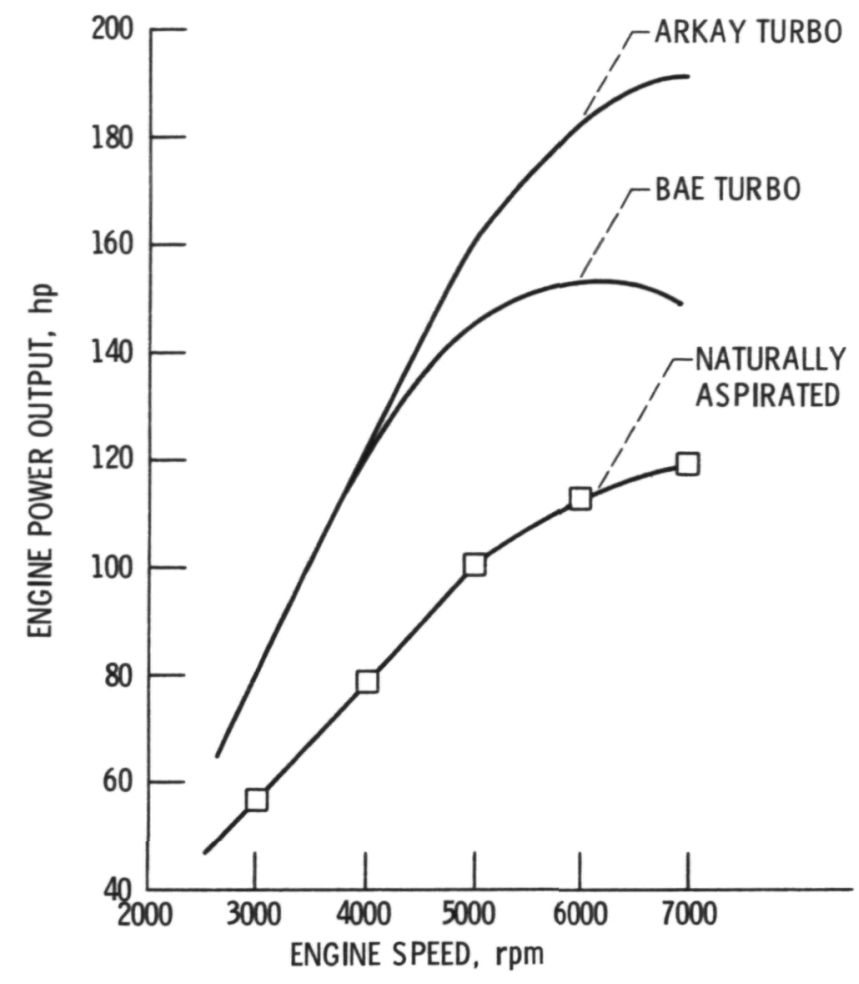

Figure 14. - Performance comparison of turbocharged and naturally aspirated rotary engine.

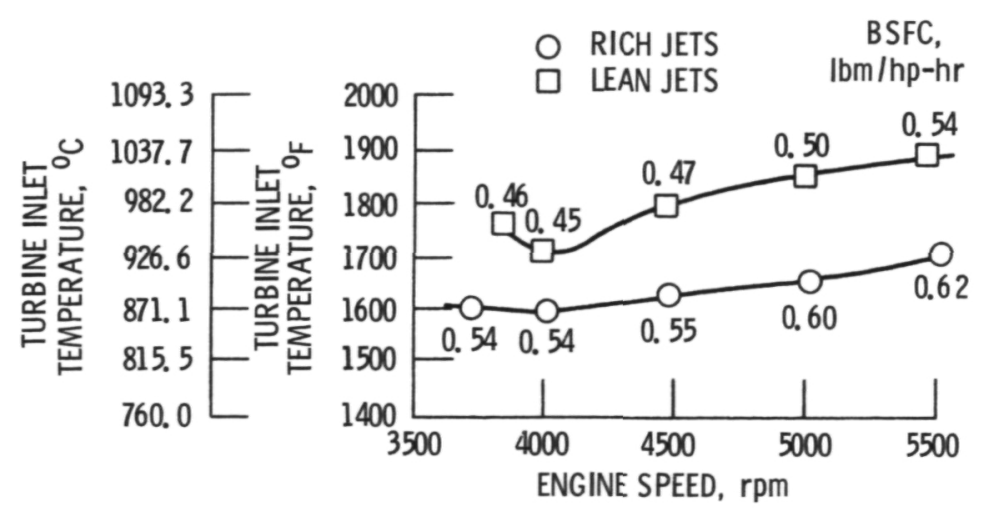

Figure 15. - Turbine inlet temperature versus speed for rich and lean carburetor jets at a constant power of $105 \mathrm{bhp}, 78 \mathrm{~kW}$. 


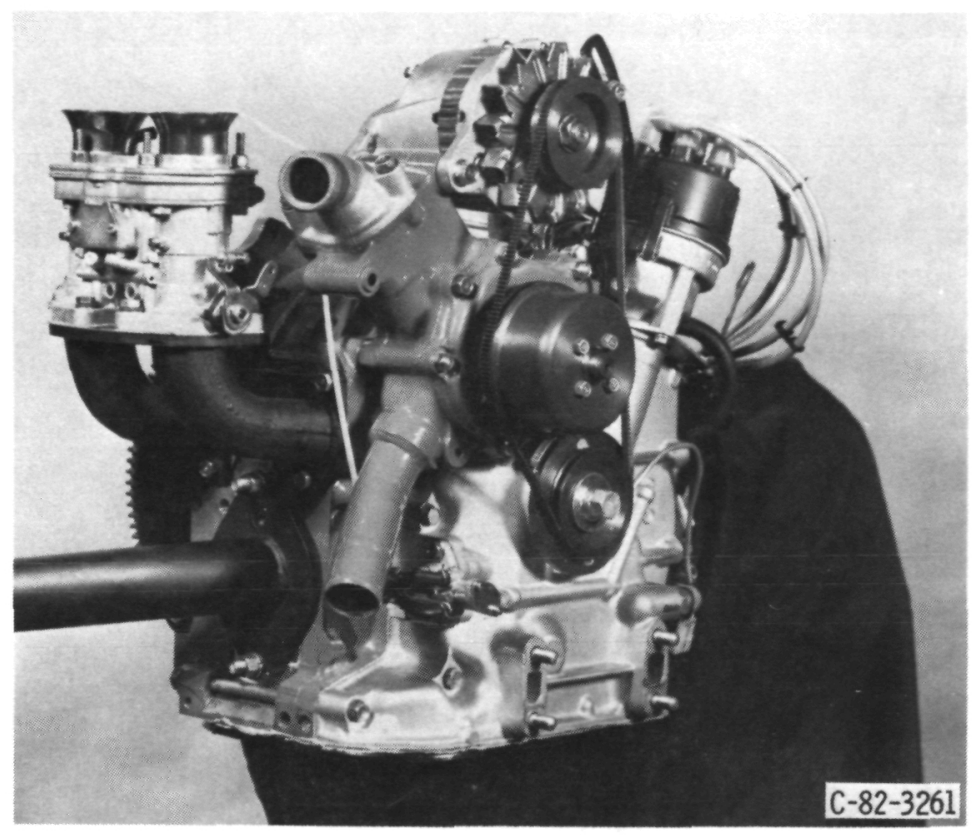

Figure 16. - Single rotor high perfor mance rotary engine.

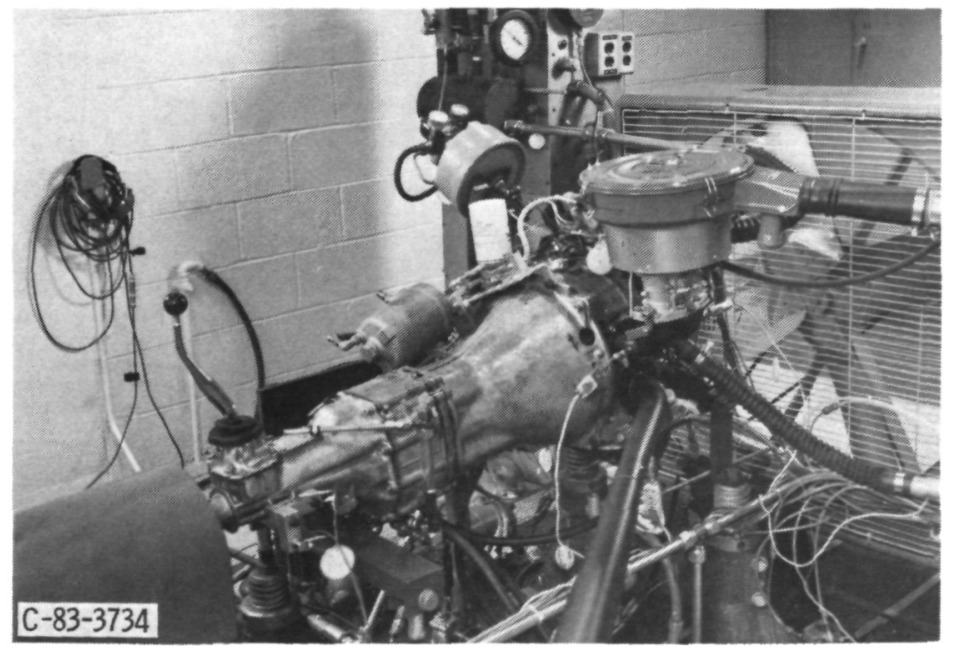

Figure 17. - Single rotor engine test facility. 


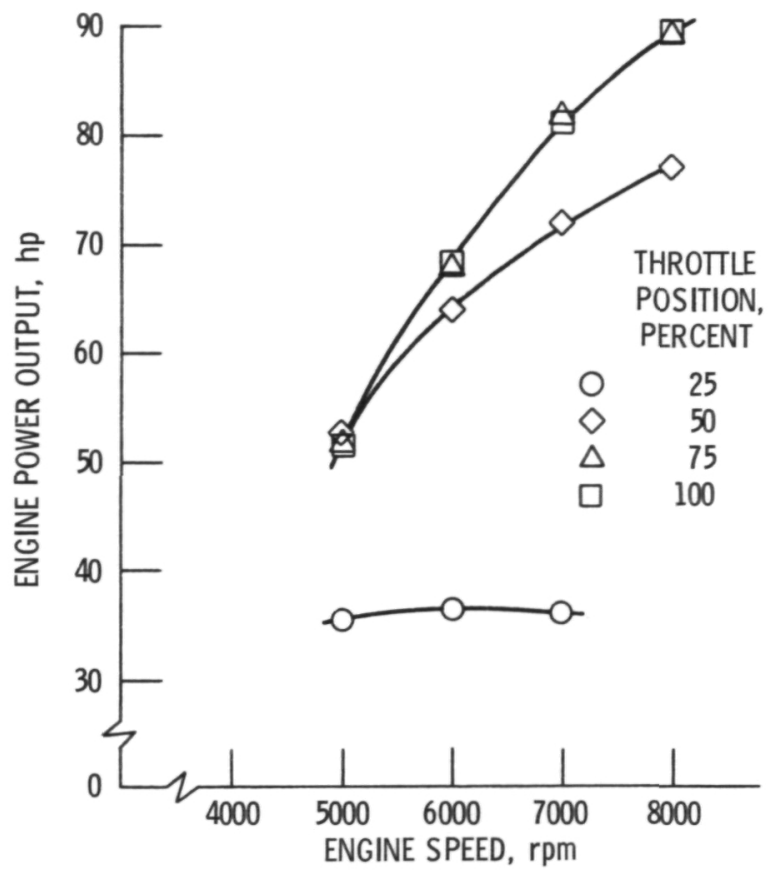

Figure 18. - Preliminary performance data for the single rotor-bridge ported rotary engine.

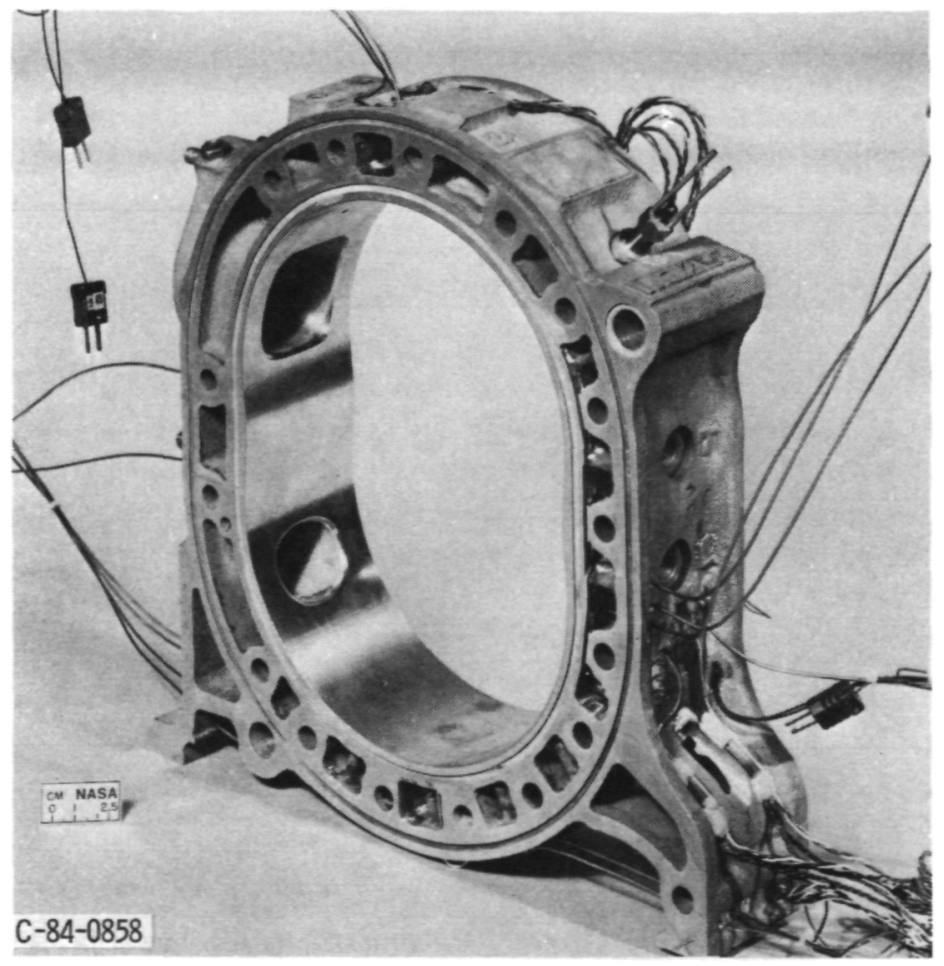

Figure 19. - Instrumented rotor housing. 


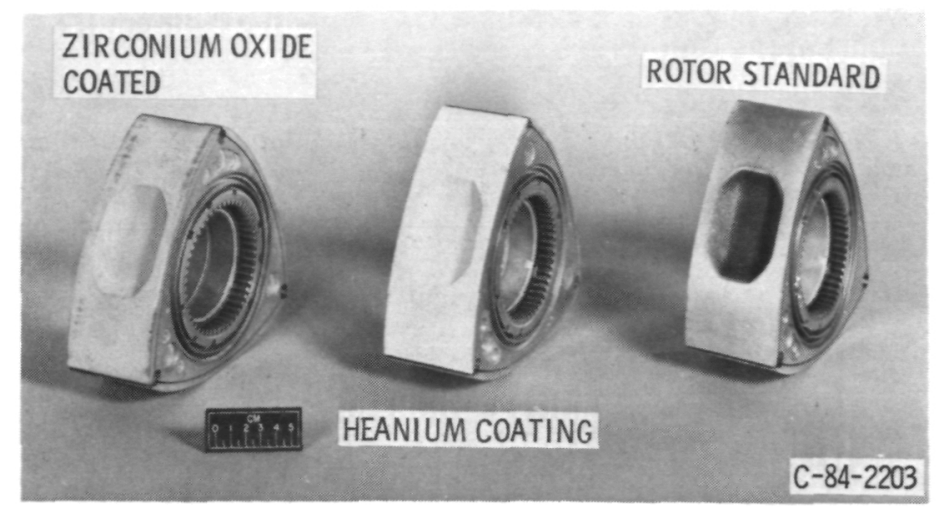

Figure 20. - Standard and ceramic coated rotors.

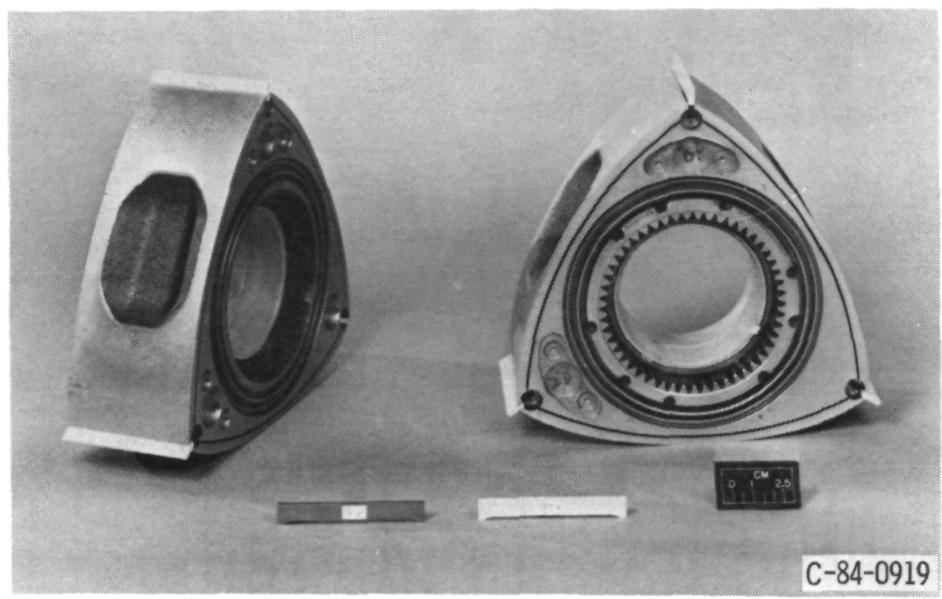

Figure 21. - Partially stabilized zirconium apex seals in standard rotor.

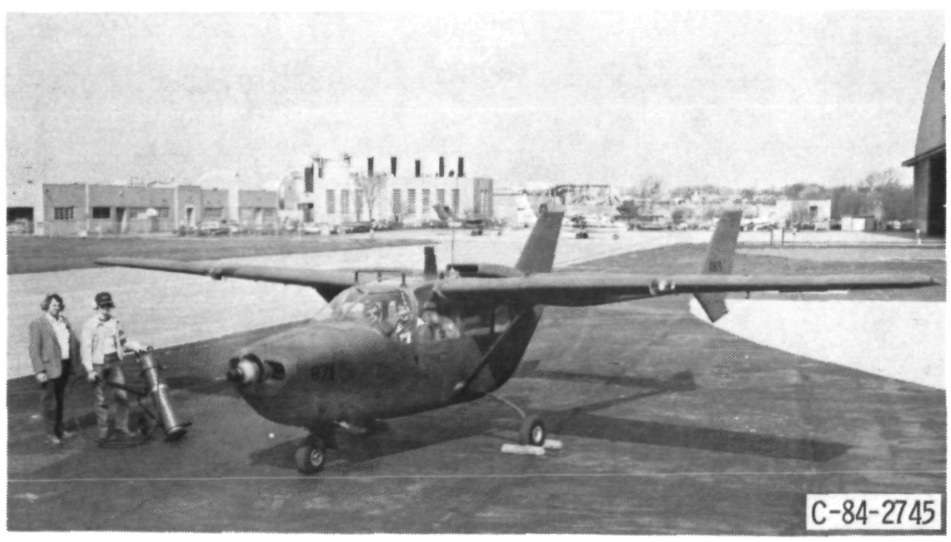

Figure 22. 02A Cessna skymaster ground test. 


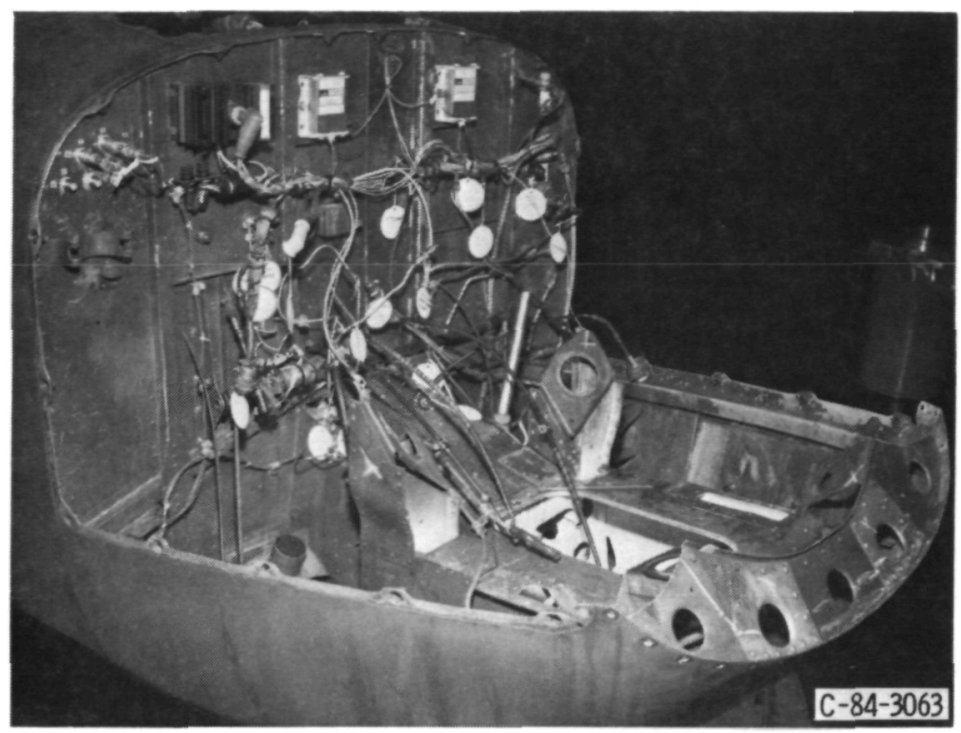

Figure 23. - Cessna skymaster front nacelle.

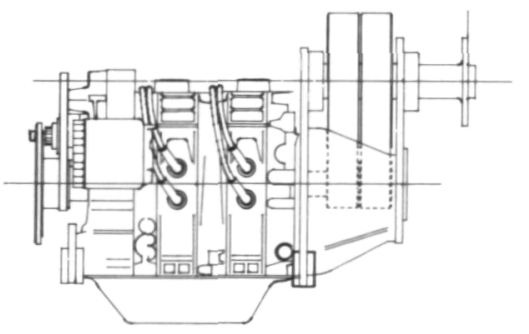

(a) Side view.

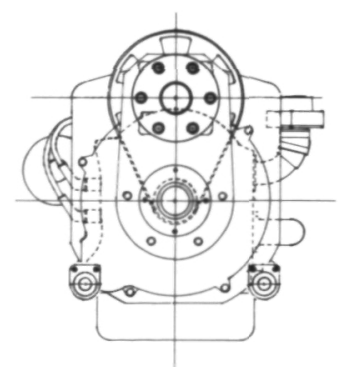

(b) Front view.

Figure 24 - Rotary engine with cog-belt propellor reduction system. 


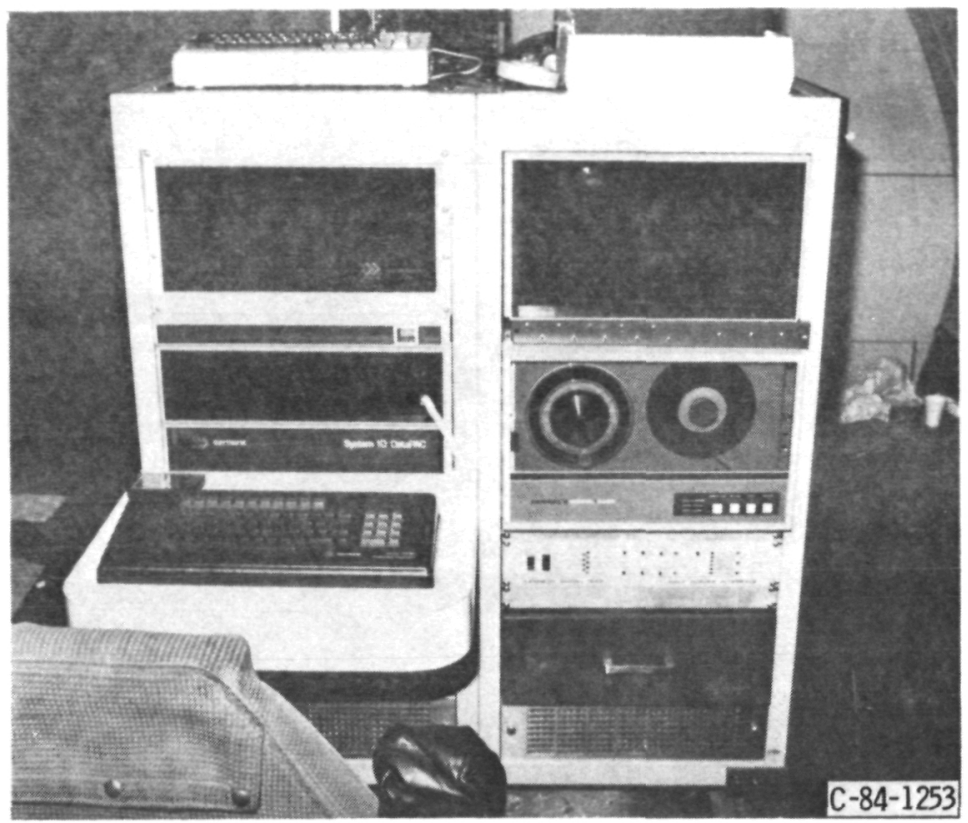

Figure 25. - Data collection system.

- VALIDATE ENGINE/DYNAMOMETER AND ENGINE/PROP TEST DATA

- EVALUATE AIRCRAFT DUTY CYCLE AND PROPELLER INDUCED DYNAMICS AND VIBRATIONS ON ENGINE AND ITS COMPONENTS

- EVALUATE ENGINE LIQUID COOLING/RADIATOR CONFIGURATION AND INSTALLATION CHARACTERISTICS

- IDENTIFY ROTARY ENGINE/GEARBOX CONFIGURATION/INSTALLATION AND NOISE PROBLEMS

- CONDUCT PERFORMANCE AND WEAR RATE TESTS ON THE ENGINE AND ITS COMPONENTS (i. e., SEALS)

- EVALUATE ENGINE/TURBOCHARGER INSTALLATION CHARACTERISTICS AND PERFORMANCE

- EVALUATE ROTARY ENGINE CONTROLS (SINGLE LEVER) FOR AIRCRAFT DUTY CYCLES

Figure 26. - Ground test aircraft test program. 


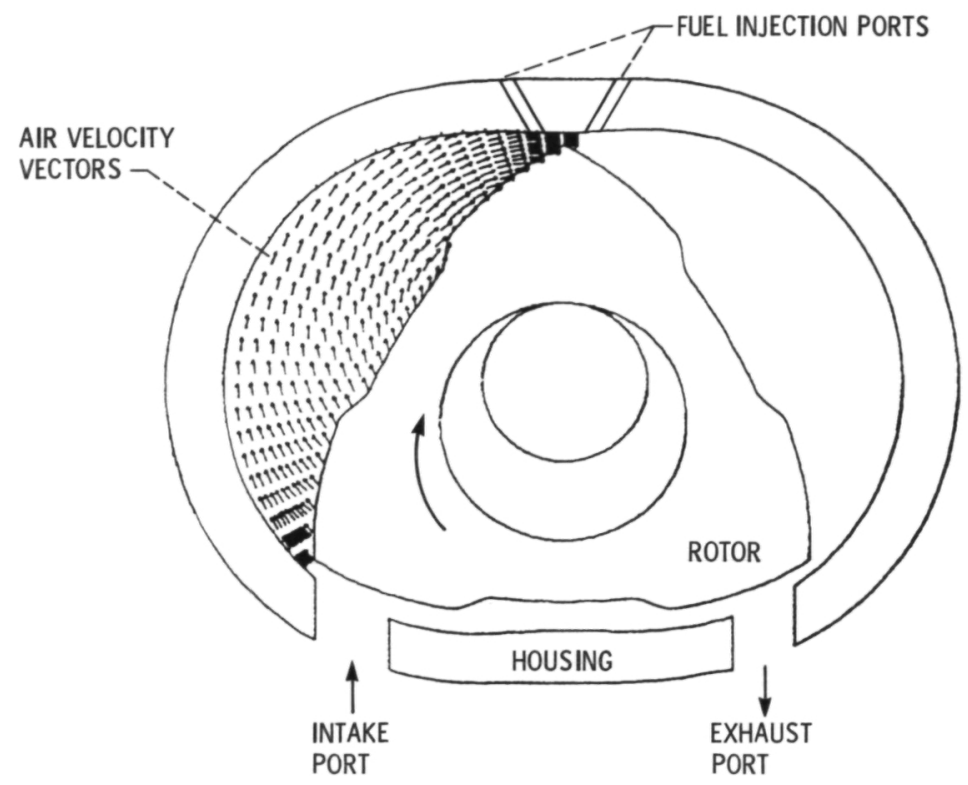

Figure 27. - RCE two-dimensional idealized airflow model output at beginning of compression. 


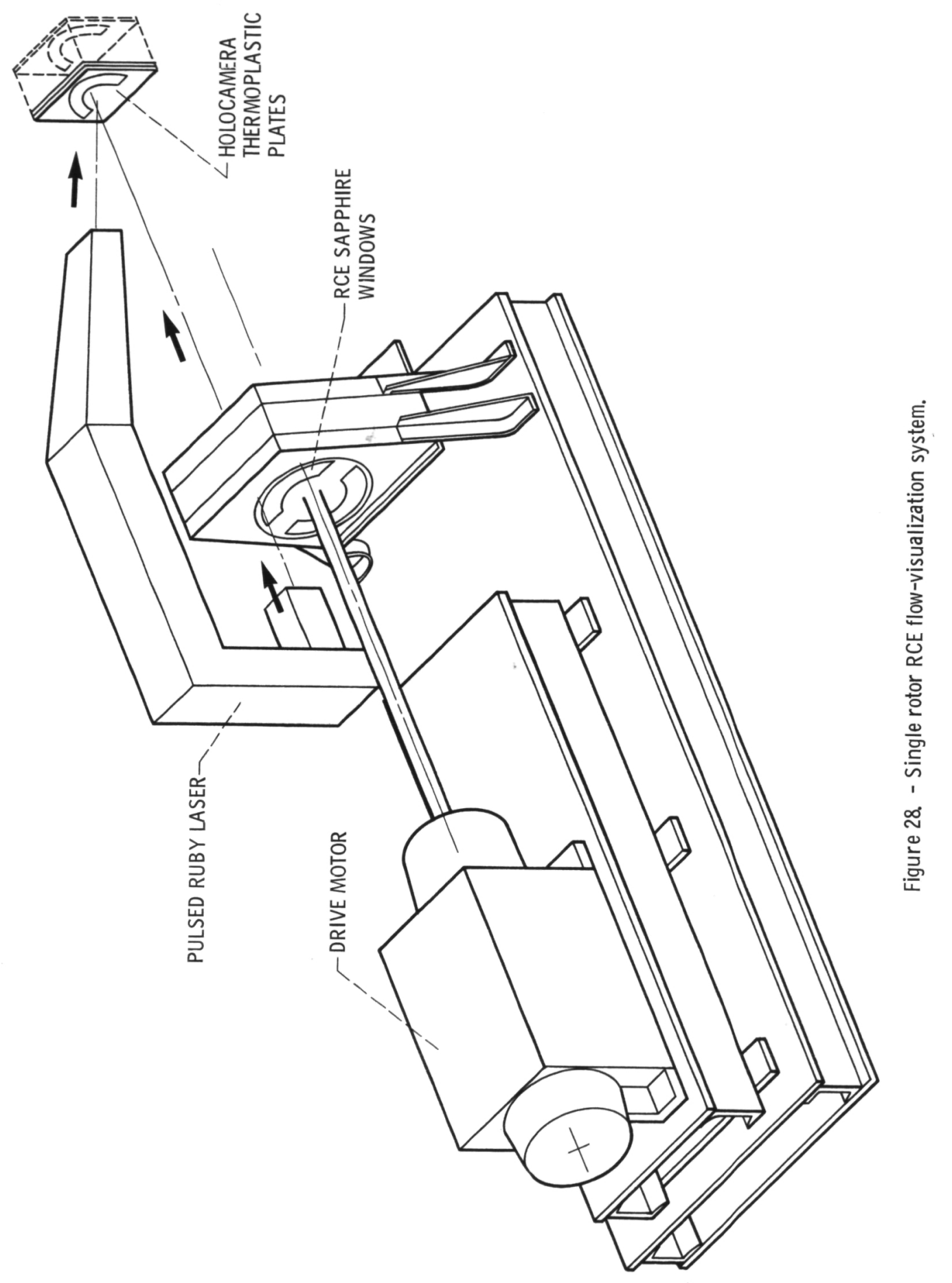




\begin{tabular}{|c|c|c|c|}
\hline $\begin{array}{l}\text { 1. Report No. } \\
\text { NASA TM- } 83699\end{array}$ & 2. Government Accession No. & \multicolumn{2}{|c|}{ 3. Recipient's Catalog No. } \\
\hline \multicolumn{2}{|l|}{ 4. Titte and Subtitle } & \multicolumn{2}{|l|}{ 5. Report Date } \\
\hline \multicolumn{2}{|c|}{ An Overview of the NASA Rotary Engine Research $P$} & \multicolumn{2}{|c|}{$\begin{array}{l}\text { 6. Pertorming Organization Code } \\
505-40-62\end{array}$} \\
\hline \multirow{2}{*}{\multicolumn{2}{|c|}{$\begin{array}{l}\text { 7. Author(s) } \\
\text { Phillip R. Meng, William F. Hady, and } \\
\text { Richard F. Barrows }\end{array}$}} & \multicolumn{2}{|c|}{$\begin{array}{l}\text { 8. Performing Organization Report No. } \\
\text { E-2157 }\end{array}$} \\
\hline & & \multicolumn{2}{|l|}{ 10. Work Unit No. } \\
\hline \multirow{2}{*}{\multicolumn{2}{|c|}{$\begin{array}{l}\text { 9. Performing Organization Name and Address } \\
\text { National Aeronautics and Space Administration } \\
\text { Lewis Research Center } \\
\text { Cleveland, Ohio } 44135\end{array}$}} & \multirow{2}{*}{\multicolumn{2}{|c|}{ 11. Contract or Grant No. }} \\
\hline & & & \\
\hline \multirow{2}{*}{\multicolumn{2}{|c|}{$\begin{array}{l}\text { 12. Sponsoring Agency Name and Address } \\
\text { National Aeronautics and Space Administration } \\
\text { Washington, D.C. } 20546\end{array}$}} & \multicolumn{2}{|c|}{$\begin{array}{l}\text { 13. Type of Report and Period Covered } \\
\text { Technical Memorandum }\end{array}$} \\
\hline & & \multicolumn{2}{|c|}{ 14. Sponsoring Agency Code } \\
\hline \multicolumn{4}{|c|}{$\begin{array}{l}\text { 15. Supplementary Notes } \\
\text { Prepared for the } 1984 \text { West Coast International Meeting sponsored by the Society of } \\
\text { Automotive Engineers, San Diego, California, August } 6-9,1984 \text {. }\end{array}$} \\
\hline \multicolumn{4}{|c|}{$\begin{array}{l}\text { 16. Abstract } \\
\text { This paper presents a brief overview and technical highlights of the research } \\
\text { efforts and studies on rotary engines over the last several years at the NASA } \\
\text { Lewis Research Center. The review covers the test results obtained from turbo- } \\
\text { charged rotary engines and preliminary results from a high performance single- } \\
\text { rotor engine. Combustion modeling studies of the rotary engine and the use of a } \\
\text { Laser Doppler Velocimeter to confirm the studies are discussed. An in-house pro- } \\
\text { gram in which a turbocharged rotary engine was installed in a Cessna Skymaster } \\
\text { for ground test studies is also covered. Details are presented on single-rotor } \\
\text { stratified-charge rotary engine research efforts, both in-house and on contract. }\end{array}$} \\
\hline $\begin{array}{l}\text { 17. Key Words (Suggested by Author(s)) } \\
\text { Aircraft propulsion } \\
\text { Rotary engine }\end{array}$ & $\begin{array}{l}\text { 18. Distrib } \\
\text { Unc1 } \\
\text { STAR }\end{array}$ & $\begin{array}{l}\text { d }- \text { unlimite } \\
\text { ry } 07\end{array}$ & \\
\hline $\begin{array}{r}\text { 19. Security Classif. (of this report) } \\
\text { Unclassi fied }\end{array}$ & $\begin{array}{l}\text { 20. Security Classif. (of this page) } \\
\text { Unclass i fied }\end{array}$ & 21. No. of pages & 22. Price ${ }^{-}$ \\
\hline
\end{tabular}

"For sale by the National Technical Information Service, Springfield, Virginia 22161 
National Aeronautics and Space Administration

Washington, D.C.

20546

Official Business

Penalty for Private Use, $\mathbf{5 3 0 0}$
SPECIAL FOURTH CLASS MAIL BOOK

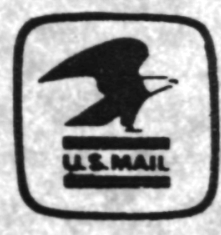

Pootege and Fees Paid National Aeronautics and Spece Administration NASA-45 